\title{
Water Management and Plant Performance in a Changing Climate: Introduction to Colloquium
}

\author{
Gladis M. Zinati \\ Rutgers University, Department of Plant Biology and Pathology, 59 Dudley Road, New Brunswick, NJ 08901
}

\begin{abstract}
Climate change refers to any significant shift or variability in temperature, precipitation, humidity, light, or wind. These changes may be of relatively short duration or last for an extended period that could be decades or longer [Intergovernmental Panel on Climate Change (IPCC), 2007)]. Throughout history, earth's climate has been changing naturally. However, the rapid warming we have been witnessing in the past several decades is not solely the result of natural processes. Some are attributed to an increase in anthropogenic activities such as burning fossil fuels for the production of personal and commercial transportation, deforestation, and various agricultural and industrial practices (U.S. Environmental Protection Agency, 2010). With the increase in the world population from 1.25 billion in 1850 to 6.5 billion in 2005 , world energy consumption has increased $\approx 40$ times (Lal, 2007). The earth's atmospheric carbon dioxide $\left(\mathrm{CO}_{2}\right)$ concentration was $\approx 280 \mu \mathrm{mol} \cdot \mathrm{mol}^{-1}$ until the 1800 s. It increased exponentially during the industrial era reaching $315 \mu \mathrm{mol} \cdot \mathrm{mol}^{-1}$ in 1957 and $362 \mu \mathrm{mol} \cdot \mathrm{mol}^{-1}$ in 1994 (Schimel et al.,
\end{abstract} 1994). Human activities have increased atmospheric concentrations of greenhouse gases such as $\mathrm{CO}_{2}$, methane $\left(\mathrm{CH}_{4}\right)$, and nitrous oxide $\left(\mathrm{N}_{2} \mathrm{O}\right)$, which occur naturally in the atmosphere (IPCC, 2007) resulting in a $0.74{ }^{\circ} \mathrm{C}$ rise in the global average surface temperature to approximately over the past 100 years (Trenberth et al., 2007). As of 2010, the atmospheric $\mathrm{CO}_{2}$ concentration is $388 \mu \mathrm{mol} \cdot \mathrm{mol}^{-1}$ and it is expected to increase to $\approx 450 \mu \mathrm{mol} \cdot \mathrm{mol}^{-1}$ by 2030 and $700 \mu \mathrm{mol} \cdot \mathrm{mol}^{-1}$ by 2050 (IPCC, 2001) as the world's population approaches nine billion (United Nations, Department of Economic and Social Affairs Population Division, 2009).

A number of studies have shown positive effects on plant growth and productivity from an increase in atmospheric $\mathrm{CO}_{2}$ concentration (Kimball et al., 2002). An increase in $\mathrm{CO}_{2}$ concentration (from $330 \mu \mathrm{mol} \cdot \mathrm{mol}^{-1}$ to 660 $\mu \mathrm{mol} \cdot \mathrm{mol}^{-1}$ ) increases yields of $\mathrm{C}_{3}$ crops [e.g., soybeans (Glycine max L.), cotton (Gossypium spp. L.), alfalfa (Medicago sativa L.), wheat (Triticum aestivum L.), rice (Oryza sativa L.), barley (Hordeum vulgare L.), and potatoes (Solanum tuberosum L.)] by $33 \%$ and yields of

Received for publication 8 Oct. 2010. Accepted for publication 10 Nov. 2010.

I thank George Wulster and A.J. Both for reviewing this manuscript.

This paper was part of the colloquium "Water Management and Plant Performance in a Changing Climate" held 4 Aug. 2010 at the ASHS Conference, Palm Desert, CA, and sponsored by the Water Utilization and Plant Performance in a Changing Climate (WUM) Working Group.

e-mail zinati@aesop.rutgers.edu.
$\mathrm{C}_{4}$ crops $\{$ e.g., corn [Zea mays] and sorghum [Sorghum bicolor (L.) Moench. $\}$ by $10 \%$ (Kimball, 1983; Long et al., 2006; Pinter et al., 2000; U.S. Climate Change Science Program, 2008). In addition, studies showed that $\mathrm{CO}_{2}$ enrichment alone could boost water use efficiency and increase yield of waterlimited crops (e.g., grains) (Drake et al., 1997; Idso and Idso, 1994). For example, in addition to increases in yield, $\mathrm{CO}_{2}$ enrichment increases water use efficiency (WUE) in wheat (Hunsaker et al., 1996), soybean (Jones et al., 1985a, 1985b), and rice (Oryza sativa L.) (Baker et al., 1990). Similar observations reported by Conley et al. (2001) indicted that cumulative evapotranspiration of sorghum was reduced without a loss in yield. Other beneficial effects were documented by Wechsung et al. (1999) on the increase of root growth and biomass of wheat under dry conditions and that of cotton (Rogers et al., 1992) as a result of $\mathrm{CO}_{2}$ enrichment.

Projected increases in $\mathrm{CO}_{2}$ and air temperature will continue to contribute to climate warming in the next century (Alcamo et al., 1996; IPCC, 2001). The northern high latitudes have warmed by $\approx 0.8^{\circ} \mathrm{C}$ since the early 1970s (Hansen et al., 1999). Warming is predicted to be greatest at high northern latitudes during fall and winter (IPCC, 2007) with reduced rainfall in the subtropics and increased precipitation in eastern America, northern Europe, and parts of Asia. Such changes appear to have a profound effect on plant periodicity as has been found in Europe (Menzel and Fabian, 1999), and plant phenology (IPCC, 2001), especially for plants that depend on accumulation of degree-days to reach flowering or fruiting (Peñuelas and Filella, 2001). The increase in temperature may extend the growing season (longer crop cycle), i.e., early planting and late harvest time will be anticipated (Porter, 2005). It has been documented that flowering had been $\approx 1$ week earlier in the Mediterranean plant species for 1952-2000 (Peñuelas et al., 2002), in Hungary for 1851-1994 (Walkovszky, 1998), in Wisconsin for 1936-1998 (Bradley et al., 1999), and in Washington, DC, for 19701999 (Abu-Asab et al., 2001).

It is expected that the production of certain crops may shift across regions as a result of climate change. Increases in temperature will cause the optimum crop growth latitude to move northward. For example, yields of some agronomic crops such as soybean are expected to decrease in southern U.S. states (U.S. Climate Change Science Program, 2008) and increase in the Midwest (Boote et al., 1996, 1997). Similarly, warming temperatures will cause production of many cool-season vegetable crops [such as potato, lettuce (Lactuca sativa L.), broccoli (Brassica oleracea L.), and spinach (Spinacea oleracea L.)] to decline. In addition, it will negatively impact fruit trees such as apples [Malus Xsylvestris (L.) Mill. domestica (Borkh.) Mansf.] that require a certain amount of chilling (Hartfield et al., 2008). In northern temperate areas, heat-demanding warm-season crops [e.g., corn and sunflower (Helianthus annuus)] are projected to replace many of the present grain cereals and oilseed crops (Olesen and Bindi, 2002). Thus, the impact of climate change on agriculture will lead to intensified production in northern Europe and less in southern Europe exacerbated by a reduction in water use for irrigation resulting from increased water scarcity (Alcamo et al., 2007; Olesen and Bindi, 2002).

The effect of high temperature may surpass the impact of water availability for plants. For example, under well-watered conditions, when increases in temperature exceed the temperature threshold for pollination, grains may not produce seed and the quality of vegetable crops (e.g., tomato, Lycopersicon esculentum Mill.) may decrease (Kunkel et al., 2008). The impact of night temperature on plant growth and yield is as important as that of day temperature. Warmer nights increase plant respiration rates, resulting in further depletion of carbohydrates and yield reduction of fruits and vegetables [e.g., snap beans (Phaseolus vulgaris L.)] (Arevalo, 2008). Bud, flower, and fruitlet abscission is commonly found in tomato plants grown under high night temperatures, especially because tomatoes require lower night than day temperatures (Peet et al., 1998; Sato et al., 2004).

Increases in the average global air temperature will likely lead to changes in precipitation and atmospheric moisture and such changes may vary from region to region (IPCC, 2007). Although some regions (e.g., tropics) will experience more frequent and intense precipitation events, precipitation is expected to decrease in other regions (e.g., the Mediterranean, northern Africa, northern Sahara, Central America, the American Southwest, and southwestern Australia during winter).

Water scarcity, as a result of changes in precipitation patterns and intensity and decreases in natural water storage capacity from glacier or snowmelt-fed river basins, will increase the competition between agricultural and urban users as population growth increases. Under climate change, water and its availability and quality will create bigger challenges than energy security (IPCC, 2008). Agriculture is the dominant user of fresh water (Gleick, 2003a, 2003b), and demand for water will continue to increase with increases in population and economic growth (Rosegrant et al., 2009). It is anticipated that the world's population will approach nine billion by 2050 (United Nations, Department of Economic and Social 
Affairs Population Division, 2009). However, sharp increases in water demands are expected from industrial, commercial, and urban users in the next 50 years (Kondratyev et al., 2003). Thus, heightened demand for water will have major political and economic impacts for maintaining food security throughout the world (Rosegrant and Cai, 2001). By the end of this century, agricultural users are expected to have less fresh water and more access to low-quality water sources for irrigation. Shannon and Grieve (2000) reported that low-quality water can be used during specific growth stages of plants and the potential water use may be higher for crops with higher yield potentials such as pac choi $\{[\mathrm{New}$ Zealand spinach (Tetragonia tetragonioides Pall.) O. Kuntze] vs. orach [Atriplex hortensis L.]\}. It is documented that the use of low-quality water with high-quality water in successive applications improves the quality of many fruits and vegetables, for example, by increasing sugar content in cantaloupe (Cucumis melo L.) (Shannon and Francois, 1978), amount of fatty acids in safflower (Carthamus tinctorius L.) (Irving et al., 1988), and soluble solids content (Pasternak et al., 1986) in processing tomato (Grattan et al., 1987) and asparagus spears (Asparagus officinalis L.) (Francois, 1987).

Research pertaining to the effects of climate change on water management and its impact on plant response is the need of the hour. Efforts must be taken to assess the challenges faced by the agricultural sector taking into account the fast-growing population and economic development in a changing climate. The impacts of climate change on agriculture and water resources are of great concern to scientists and policymakers. In view of these challenges, the American Society for Horticultural Science Water Utilization and Management working group convened a colloquium titled "Water Management and Plant Performance in a Changing Climate" in 2010 to address the: 1) general aspects of water security and plant performance under increased concentration of atmospheric $\mathrm{CO}_{2}$ and temperature; 2) selection of drought-tolerant plant species; and 3) practical techniques and tools that can be used to detect stress in various crops. The six presentations that follow examine and discuss the challenges inherent in impact of climate change on availability of water and its impact on agricultural production in various regions and offering a series of priority targets for future research. O'Neill and Dobrowolski (2011) outline some of the scientific and educational challenges of water resource management in agriculture and emphasize six possible intervention opportunities to achieve agricultural water security. The increase in water demand for irrigating agricultural crops in some areas might be partially offset by more efficient use of water by plants as a result of rising atmospheric carbon dioxide. Prior et al. (2011) report that plants can be stimulated by the rising level of atmospheric $\mathrm{CO}_{2}$ as reflected by increased photosynthesis, growth, and WUE. They discuss priority research areas in horticulture such as identifying drought-tolerant species, soil carbon storage potential, green- house gas emissions, and potential pest problems to help the horticulture industry develop best management practices for meeting the challenges of a changing environment. Increases in $\mathrm{CO}_{2}$ levels increase plant growth and elevated temperatures increase plant transpiration and the water requirement of plants. Leaves are key factors in the global water exchange cycle. Bauerle and Bowden (2011) address the effects of leaf width on transpiration, boundary layer conductance, and leaf temperature in red maple (Acer rubrum L.) genotypes. Kjelgren et al. (2011) present an overview of tropical urban forestry in Southeast Asia and focus on the response of tropical tree species that successfully tolerate the urban heat island and droughty urban soils in a changing climate. Ecological models of climate change impacts on tropical forest type distribution can yield insights into selection of tree species better suited to urban conditions in tropical cities. Shackel (2011) demonstrates the use of midday stem water potential as a reliable and practical measure of stress in woody fruit trees and vines and gives an example of its usefulness in applying regulated deficit irrigation for the purpose of increasing the field-scale uniformity of hull split in almonds (Prunus dulcis Mill.). Complementing such a technique is the use of sensors in the field to improve irrigation scheduling of vegetable crops. Shock and Wang (2011) discuss the use of soil moisture tension as a powerful measurement to improve crop productivity and elaborate on the pros and cons of using various sensors for irrigation scheduling.

As the climate continues to change in the next few decades or century, water availability (quantity and quality) and water management will continue to be important components for both agricultural production and urban landscapes. To cope with climate change, the implementation of adaptive strategies for resolving water stress in many agricultural regions becomes an imminent need. These strategies may include 1) the development and use of droughttolerant and drought-resistant crops; 2) changes in agricultural land use and management, soil cultivation, fertilization, planting and harvesting times; 3) the implementation of WUE measures; 4) increase in the use of recycled and low-quality water for irrigation; and 5) the development of practical tools for irrigation scheduling and measuring plant water stress.

\section{Literature Cited}

Abu-Asab, M.S., P.M. Peterson, S.G. Shetler, and S.S. Orli. 2001. Earlier plant flowering in spring as a response to global warming in the Washington, DC, area. Biodivers. Conserv. 10: 597-612.

Alcamo, J., G.J.J. Kreileman, J.C. Bollen, G.J. van den Born, R. Gerlagh, M.S. Krol, A.M.C. Toet, and H.J.M. de Vries. 1996. Baseline scenarios of global environmental change. Glob. Environ. Change 6:261-303.

Alcamo, J., J.M. Moreno, B. Novaky, M. Bindi, R. Corobov, R.N.J. Devoy, C. Giannakopoulos, E. Martin, J.E. Olesen, and A. Shvidenko. 2007. Europe. Climate change 2007: Impacts, adaptation and vulnerability, p. 541-580. In: Parry, M.L., O.F. Canziani, J.P. Palutikof, P.J. van der
Linden, and C.E. Hanson (eds.). Contribution of working group II to the Fourth Assessment Report of the Intergovernmental Panel on Climate Change. Cambridge Univ. Press, Cambridge, UK.

Arevalo, L.M. 2008. Physiological response of cotton to high night temperatures. Amer. J. Plant Sci. Biotech. 2:63-68.

Baker, J.T., L.H. Allen, Jr., K.J. Boote, P. Jones, and J.W. Jones. 1990. Rice photosynthesis and evapotranspiration in subambient, ambient, and super-ambient carbon dioxide concentrations. Agron. J. 82:834-840.

Bauerle, W.L. and J.D. Bowden. 2011. Predicting transpiration response to climate change: Insights on physiological and morphological interactions that modulate water exchange from leaves to canopies. HortScience 46:163-166.

Boote, K.J., J.W. Jones, and N.B. Pickering. 1996. Potential uses and limitations of crop models. Agron. J. 88:704-716.

Boote, K.J., N.B. Pickering, and L.H. Allen, Jr. 1997. Plant modeling: Advances and gaps in our capability to project future crop growth and yield in response to global climate change. In: Allen, L.H., Jr., M.B. Kirkman, D.M. Olszyk, and C.E. Whitman (eds.). Advances in carbon dioxide effects research. ASA Special Publication No. 61. ASA-CSSA-SSSA, Madison, WI.

Bradley, N.L., A.C. Leopold, J. Ross, and W. Huffaker. 1999. Phenological changes reflect climate change in Wisconsin. Proc. Natl. Acad. Sci. USA 96:9701-9704.

Conley, M.M., B.A. Kimball, T.J. Brooks, P.J. Pinter Jr., D.J. Hunsaker, G.W. Wall, N.R. Adam, R.L. LaMortel, A.D. Matthias, T.L. Thompson, S.W. Leavitt, M.J. Ottman, A.B. Cousins, and J.M. Triggs. 2001. $\mathrm{CO}_{2}$ enrichment increases water-use efficiency in sorghum. New Phytol. 151:407-412.

Drake, B.G., M.A. Gonzalez-Meler, and S.P. Long. 1997. More efficient plants: A consequence of rising atmospheric $\mathrm{CO}_{2}$ ? Annu. Rev. Plant Physiol. Plant Mol. Biol. 48:609-639.

Francois, L.E. 1987. Salinity effects on asparagus yield and vegetative growth. J. Amer. Soc. HortScience 112:432-436.

Gleick, P.H. 2003a. Global freshwater resources: Soft-path solutions for the 21 st century. Sci. 302:1524-1526

Gleick, P.H. 2003b. Water use. Annu. Rev. Environ. Resour. 28:275-314.

Grattan, S.R., C. Shennan, D.M. May, J.P. Mitchell, and R.G. Burau. 1987. Use of drainage water for irrigation of melons and tomatoes. Calif. Agr. 41:27-28.

Hansen, J., R. Ruedy, J. Glascoe, and M. Sato 1999. GISS analysis of surface temperature change. J. Geophys. Res. 104:30997-31022.

Hartfield, J., K. Boote, P. Fay, L. Hahn, C. Izaurralde, B.A. Kimball, T. Mader, J. Morgan, D. Ort, W. Polley, A. Thomson, and D. Wolfe. 2008. Agriculture, p. 21-74. In: Backlund, P. A. Janetos, D. Schimel, J. Hatfield, K. Boote, P. Fay, L. Hahn, C. Izaurralde, B.A. Kimball, T. Mader, J. Morgan, D. Ort, W. Polley, A. Thomson, D. Wolfe, M.G. Ryan, S.R. Archer, R. Birdsey, C. Dahm, L. Health, J. Hicke, D. Hollinger, T. Huxman, G. Okin, R. Oren, J. Randerson, W. Schlesinger, D. Lettenmaier, D. Major, L. Poff, S. Running, L. Hansen, D. Inouye, B.P. Kelly, L. Meyerson, B. Peterson, and R. Shaw (eds.). The effects of climate change on agriculture, land resources, water resources, and biodiversity in the United States: Synthesis and assessment product 4.3. U.S. Dept. Agr., Washington, DC.

Hunsaker, D.J., B.A. Kimball, P.J. Pinter, Jr., R.L. LaMorte, and G.W. Wall. 1996. Carbon dioxide 
enrichment and irrigation effects on wheat evapotranspiration and water-use efficiency. Amer. Soc. Agr. Eng. 39:1345-1355.

Idso, K.E. and S.B. Idso. 1994. Plant responses to atmospheric $\mathrm{CO}_{2}$ enrichment in the face of environmental constraints: A review of the past 10 years' research. Agr. For. Meteorol. 69:153-203.

Intergovernmental Panel on Climate Change. 2001. Climate change 2001 - The scientific basis: Contribution of Working Group 1 to the Third Assessment Report of the Intergovernmental Panel on Climate Change, p. 1-881. In: Houghton, J.T., Y. Ding, D.J. Griggs, M. Noguer, P.J. van der Linden, X. Dai, K. Maskell, and C.A. Johnson (eds.). Cambridge University Press, Cambridge, UK, and New York, NY.

Intergovernmental Panel on Climate Change. 2007. Climate change 2007: The physical science basis. Summary for policymakers. IPCC Working Group I Fourth Assessment Report. IPCC, Geneva, Switzerland.

Intergovernmental Panel on Climate Change. 2008. Climate change and water. IPCC Technical Paper VI of the Secretariat, p. 1-210. In: Bates, B.C., Z.W. Kundzewicz, S. Wu, and J.P. Palutikof (eds.). IPCC, Geneva, Switzerland.

Irving, D.W., M.C. Shannon, V.A. Breda, and B.E. Mackey. 1988. Salinity effects on yield and oil quality of high-linoleate and high-oleate cultivars of safflower (Carthamus tinctorius L.). J. Agr. Food Chem. 36:37-42.

Jones, P., L.H. Allen, Jr., J.W. Jones, and R. Valle. 1985a. Photosynthesis and transpiration response of soybean canopies to short- and longterm $\mathrm{CO}_{2}$ treatment. Agron. J. 77:119-126.

Jones, P., J.W. Jones, and L.H. Allen, Jr. 1985 b. Carbon dioxide effects on photosynthesis and transpiration during vegetative growth in soybeans. Proc. Soil Crop Sci. Soc. Fla. 44:129-134.

Kimball, B.A. 1983. Carbon dioxide and agricultural yield: An assemblage of analysis of 430 prior observations. Agron. J. 75:779-788.

Kimball, B.A., K. Kobayashi, and M. Bindi. 2002. Responses of agricultural crops to free-air $\mathrm{CO}_{2}$ enrichment. Adv. Agron. 77:293-368.

Kjelgren, R., Y. Trisurat, L. Puangchit, N. Baguinon, and P. Tan-Yok. 2011. Tropical street tress and climate uncertainty in Southeast Asia. HortScience 46:167-172.

Kondratyev, K.Y., V.F. Krapivin, and C.A. Varotsos. 2003. Global carbon cycle and climate change. Springer-Verlag, Berlin, Germany.

Kunkel, K.E., P.D. Bromirski, H.E. Brooks, T. Cavazos, A.V. Douglas, D.R. Easterling, K.A. Emanuel, P.Ya. Groisman, G.J. Holland, T.R. Knutson, J.P. Kossin, P.D. Komar, D.H. Levinson, and R.L. Smith. 2008. Observed changes in weather and climate extremes, p. 35-80. In: Karl, T.R. Meehl G.A., Miller C.D., Hassol S.J., Waple A.M., and W.L. Murray (eds.). Weather and climate extremes in a changing climate: Regions of focus: North America, Hawaii, Caribbean, and U.S. Pacific Islands. Synthesis and Assessment Product 3.3. U.S. Climate Change Science Program, Washington, DC.
Lal, R. 2007. Soil science and the carbon civilization. Soil Sci. Soc. Amer. J. 71:1425-1437.

Long, S.P., E.A. Ainsworth, A.D.B. Leakey, J. Nösberger, and D.R. Ort. 2006. Food for thought: Lower-than-expected crop yield stimulation with rising $\mathrm{CO}_{2}$ concentration. Science 312:1918-1921.

Menzel, A. and P. Fabian. 1999. Growing season extended in Europe. Nature 397:659.

Olesen, J.E. and M. Bindi. 2002. Consequences of climate change for European agricultural productivity, land use and policy. Eur. J. Agron. 16:239-262.

O'Neill, M.P. and J.P. Dobrowolski. 2011. Water and agriculture in a changing climate. HortScience 46:155-157.

Pasternak, D.A., Y. DeMalach, and J. Borovic. 1986. Irrigation with brackish water under desert conditions: VII. Effect of time of application of brackish water on production of processing tomatoes (Lycopersicon esculentum Mill.). Agr. Water Mgt. 12:149-158.

Peet, M.M., S. Sato, and R.G. Gardner. 1998. Comparing heat stress effects on male-fertile and male-sterile tomatoes. Plant Cell Environ. 21:225-231.

Peñuelas, J. and I. Filella. 2001. Phenology: Responses to a warming world. Science 294:793-795.

Peñuelas, J., I. Filella, and P. Comas. 2002. Changed plant and animal life cycles from 1952 to 2000 in the Mediterranean region. Glob. Change Biol. 8:531-544.

Pinter, P.J., Jr., B.A. Kimball, G.W. Wall, R.L. LaMorte, D.J. Hunsaker, F.J. Adamsen, K.F.A. Frumau, H.F. Vugts, G.R. Hendrey, K.F. Lewin, J. Nagy, J.B. Johnson, F. Wechsung, S.W. Leavitt, T.L. Thompson, A.D. Matthias, and T.J. Brooks 2000. Free-air $\mathrm{CO}_{2}$ enrichment (FACE): Blower effects on wheat canopy microclimate and plant development. Agr. For. Meteorol. 103:319-333.

Porter, J.R. 2005. Rising temperatures are likely to reduce crop yields. Nature 436:174.

Prior, S.A., G.B. Runion, S.C. Marble, H.H. Rogers, C.H. Gilliam, and H.A. Torbert. 2011. Effects of elevated atmospheric $\mathrm{CO}_{2}$ on plant growth and water relations: Implications for horticulture. HortScience 46:158-162.

Rogers, H.H., C.M. Peterson, J.N. McCrimmon, and J.D. Cure. 1992. Response of plant roots to elevated atmospheric carbon dioxide. Plant Cell Environ. 15:749-752.

Rosegrant, M.W. and X. Cai. 2001. Water scarcity and food security: Alternative futures for the 21 st century. Water Sci. Technol. 43:61-70.

Rosegrant, M.W., C. Ringler, and T. Zhu. 2009. Water for agriculture: Maintaining food security under growing scarcity. Annu. Rev. Environ. Resour. 34:205-222.

Sato, S., M. Peet, and R.G. Gardner. 2004. Altered flower retention and developmental patterns in nine tomato cultivars under elevated temperature. Sci. Hort. 101:95-101.

Schimel, D.S., I. Enting, M. Heimann, T.M. Wigley, D. Raynaud, D. Alves, and U. Siegenthaler. 1994. $\mathrm{CO}_{2}$ and the carbon cycle, p. 39-71. In: Houghton, J.T., L.G.M. Filho, J. Bruce, H. Lee,
B.A. Callander, E. Haites, N. Harris, and K. Maskell (eds.). IPCC Report. Climate change 1994. Radiative forcing of climate change. Cambridge University Press, Cambridge, UK.

Shackel, K. 2011. Plant-based approaches to deficit irrigation in trees and vines. HortScience 46: 173-177.

Shannon, M.C. and L.E. Francois. 1978. Salt tolerance of three muskmelon cultivars. J. Amer. Soc. Hort. Sci. 103:127-130.

Shannon, M.C. and C.M. Grieve. 2000. Options for using low-quality water for vegetable crops. HortScience 35:1058-1062.

Shock, C.C. and F.-X. Wang. 2011. Soil water tension, a powerful measurement for productivity and stewardship. HortScience 46:178185.

Trenberth, K.E., P.D. Jones, P. Ambenje, R. Bojariu, D. Easterling, A.K. Tank, D. Parker, F. Rahimzadeh, J.A. Renwick, M. Rusticucci, B. Soden, and P. Zhai. 2007. Observations: Surface and atmospheric climate change, p. 235-336. In: Solomon, S., D. Qin, M. Manning, Z. Chen, M. Marquis, K.B. Averyt, M. Tignor, and H.L. Miller (eds.). Climate change 2007: The physical science basis. Contribution of Working Group I to the Fourth Assessment Report of the Intergovernmental Panel on Climate Change. Cambridge Univ. Press, Cambridge, UK, and New York, NY.

United Nations, Department of Economic and Social Affairs Population Division. 2009. World population prospects: The 2008 revision. United Nations, New York, NY.

U.S. Climate Change Science Program. 2008. The effects of climate change on agriculture, land resources, water resources, and biodiversity in the United States. A report by the U.S. Climate Change Science Program and the Subcommittee on Global Change Research. Backlund, P., A. Janetos, D. Schimel, J. Hatfield, K. Boote, P. Fay, L. Hahn, C. Izaurralde, B.A. Kimball, T. Mader, J. Morgan, D. Ort, W. Polley, A. Thomson, D. Wolfe, M. Ryan, S. Archer, R. Birdsey, C. Dahm, L. Health, J. Hicke, D. Hollinger, T. Huxman, G. Okin, R. Oren, J. Randerson, W. Schlesinger, D. Lettenmaier, D. Major, L. Poff, S. Running, L. Hansen, D. Inouye, B.P. Kelly, L. Meyerson, B. Peterson, and R. Shaw. U.S. Dept. Agr., Washington, DC.

U.S. Environmental Protection Agency. 2010. Climate change indicators in the United States. USEPA \#EPA 430-R-10-007. 16 Sept. 2010. $<$ http://www.epa.gov/climatechange/indicators/ pdfs/ClimateIndicators_full.pdf/>.

Walkovszky, A. 1998. Changes in phenology of the locust tree (Robinia pseudoacacia L.) in Hungary. Intl. J. Biometeorol. 41:155-160.

Wechsung, G., F. Wechsung, G.W. Wall, F.J. Adamsen, B.A. Kimball, R.L. Garcia, P.J. Pinter, Jr., R.L. LaMorte, R.L. Garcia, and T.H. Kartschall. 1999. The effects of free-air $\mathrm{CO}_{2}$ enrichment and soil water availability on spatial and seasonal patterns of wheat root growth. Glob. Change Biol. 5:519-529. 